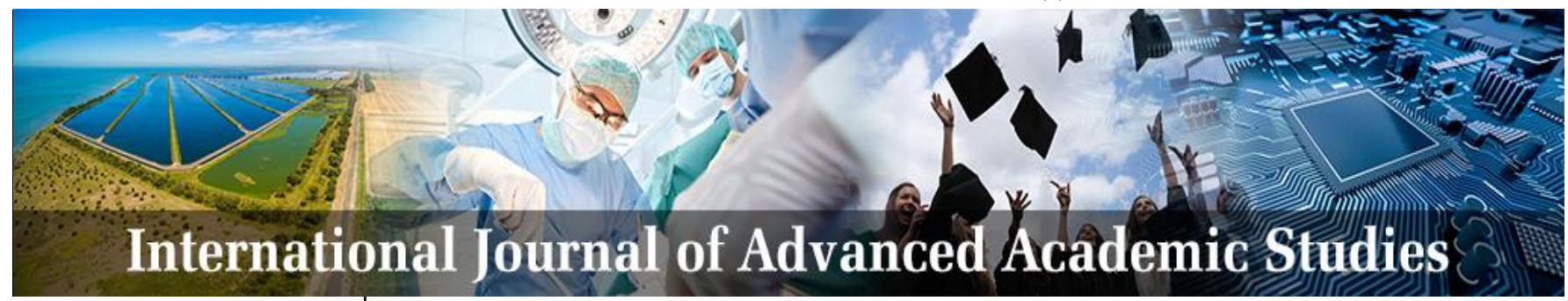

E-ISSN: 2706-8927

P-ISSN: 2706-8919

www.allstudyjournal.com

IJAAS 2021; 3(2): 24-29

Received: 13-01-2021

Accepted: 21-02-2021

Lopamudra Ganguly Ph.D., Scholar, Department of Geography, University of Calcutta, 35, Ballygunge Circular Road, Ballygunge, Kolkata, West Bengal, India

Corresponding Author: Lopamudra Ganguly Ph.D., Scholar, Department of Geography, University of Calcutta, 35, Ballygunge Circular Road, Ballygunge, Kolkata, West Bengal, India

\section{Menstruation and personal hygiene practice among tribal female of Baria village, west Bengal: A case study}

\section{Lopamudra Ganguly}

DOI: https://doi.org/10.33545/27068919.2021.v3.i2a.532

\begin{abstract}
Introduction: 'Menstrual Hygiene Management' (M.H.M.) is an essential aspect for a woman's hygiene sector, but in India, 'Menstruation' is still a taboo. Because of social bindings, rarely proper cleanliness method is followed. This present study highlighted the issues and problems related to M.H.M. (Menstrual Hygiene Management) practices in Baria village of south 24 Pargana, West Bengal. This research also comprehended how the traditional myths, social taboos and misconceptions related to menstruation are affecting rural women health and well being more extensively.

Methodology: Seventy women of age group 18-45yr in Baria village were interviewed regarding their socio-demographic profile, knowledge, and practices on menstruation. A cross-sectional study was performed to conduct the research. A pre-designed and pre-tested questionnaire was made during the study after being tested on a pilot project basis on the targeted geographical area. Door to door questioner survey in the villages was done.

Result: Results highlight that there is a massive gap in the utilization of commercial sanitary pads/napkins and cloths among the differential age group of women. Poverty and education level play a significant role in the non-use of environment-friendly sanitary products and the disposal of the used product. This research opens an arena where problems associated with 'M.H.M.' is not associated with regional aspect but also in the global ground.
\end{abstract}

Keywords: Baria village, cleanliness, infection, menstruation hygiene management, social taboos, sanitary pads

\section{Introductions}

The term 'Menstruation' is the most compulsion part of female life. The beginning of menstruation is significant landmarks in the process of physical as well as mental growth of the journey from menarche to menopause of a female (Kamaljit et al., 2012) ${ }^{[11]}$. In the physiological angel, menstruation means the periodic vaginal bleeding, with the shedding of the uterine mucosa. It is the significant signs of puberty (Majhi, 2016) ${ }^{[14]}$. Menstruation is the signal of possible fertility not only in the aspect of a bodily process but in the societal angle also. In medical perspective "Menstrual Hygiene Management" (M.H.M.) is an indivisible part of menstruation. From the beginning of human civilization, menstruation is associated with various taboos and norms; therefore, the misconception is a crucial part of menstrual practised. Research proved that about $88 \%$ of menstruating women in India could not acquire proper menstrual products and rely on unhygienic alternatives like pieces of cloths, ash, and sand on that crucial period. As a consequence, they are prone to the risk of reproductive diseases (https://www.dasra.org/resource/improving-menstrual-health-andhygiene). There is an extensive lacuna in the knowledge towards menstruation among the women. There is a superficial level of awareness and misconception about menstruation among girls when they first experience it, till menopause (Ahuja et al. 1995; Chowdary 1998; Khanna 2005 and Singh 2006) ${ }^{[2,5,12,16]}$. Social prohibitions, negative attitude of parents and society has blocked the access of women towards the right kind of information, especially in specific tribal communities because sometimes they are isolated from the other parts of the society and maintain a unique custom among their society. Further, their intense bondage with traditional beliefs, taboos, and misconceptions during menstruation has led to many gynaecological problems. However, the stringing fact is that the woman in most of the time unknown the factor ignores the fact (Bhatia et al., 1995) ${ }^{[3]}$. Many national and international studies vividly reported that the period of menstruation is highly infectionprone (Mehra, 1995) ${ }^{[13]}$. 
Repeated use of unclean cloth, improper drying of used cloth before its reuse results in harbouring of microorganisms; as a result, the spread of vaginal infections are common issues among the menstruation women (Paul, 2007) ${ }^{[15]}$. Bondage with the traditional beliefs, taboos and misconceptions during menstruation has led to severe, much health-related issues. Due to lack of personal hygiene and unsafe sanitary conditions the menstrual girls facing many gynaecological problems (Bhatia et al. 1995) ${ }^{[3]}$. Infections due to lack of menstrual hygiene have been reported in many studies (Mehra 1995) ${ }^{[13]}$.

\section{Description of the study area- in brief}

Basanti community development block is a part of the administrative division of Canning subdivision. It is under
South 24 Parganas district, West Bengal, India. This district is bounded by the latitudes $20^{\circ} 20^{\prime} \mathrm{N}$ and $22^{\circ} 06^{\prime} \mathrm{N}$ and longitudes $88^{\circ} 20^{\prime} \mathrm{E}$ and $88^{\circ} 60^{\prime} \mathrm{E}$. It is situated 56 kilometres (35 mt) from Alipore, the district headquarters (Fig 1). The total area of Basanti CD Block is 404.21 square kilometres. Location code of Baria village (study area) is 335056 as per census data. This village is located in Basanti Tehsil in West Bengal. The area is $15 \mathrm{~km}$ away from sub-district headquarter Sonakhali and $63.4 \mathrm{~km}$ away from district headquarter Alipore. The total area of the village is 547.88 hectares. As per 2019 status, Baria village comes under Gosaba assembly \& Jaynagar parliamentary constituency. Canning is the nearest town to Baria, which is approximately $20 \mathrm{~km}$ away (District Statistical Handbook, South 24 Pargana, 2011).

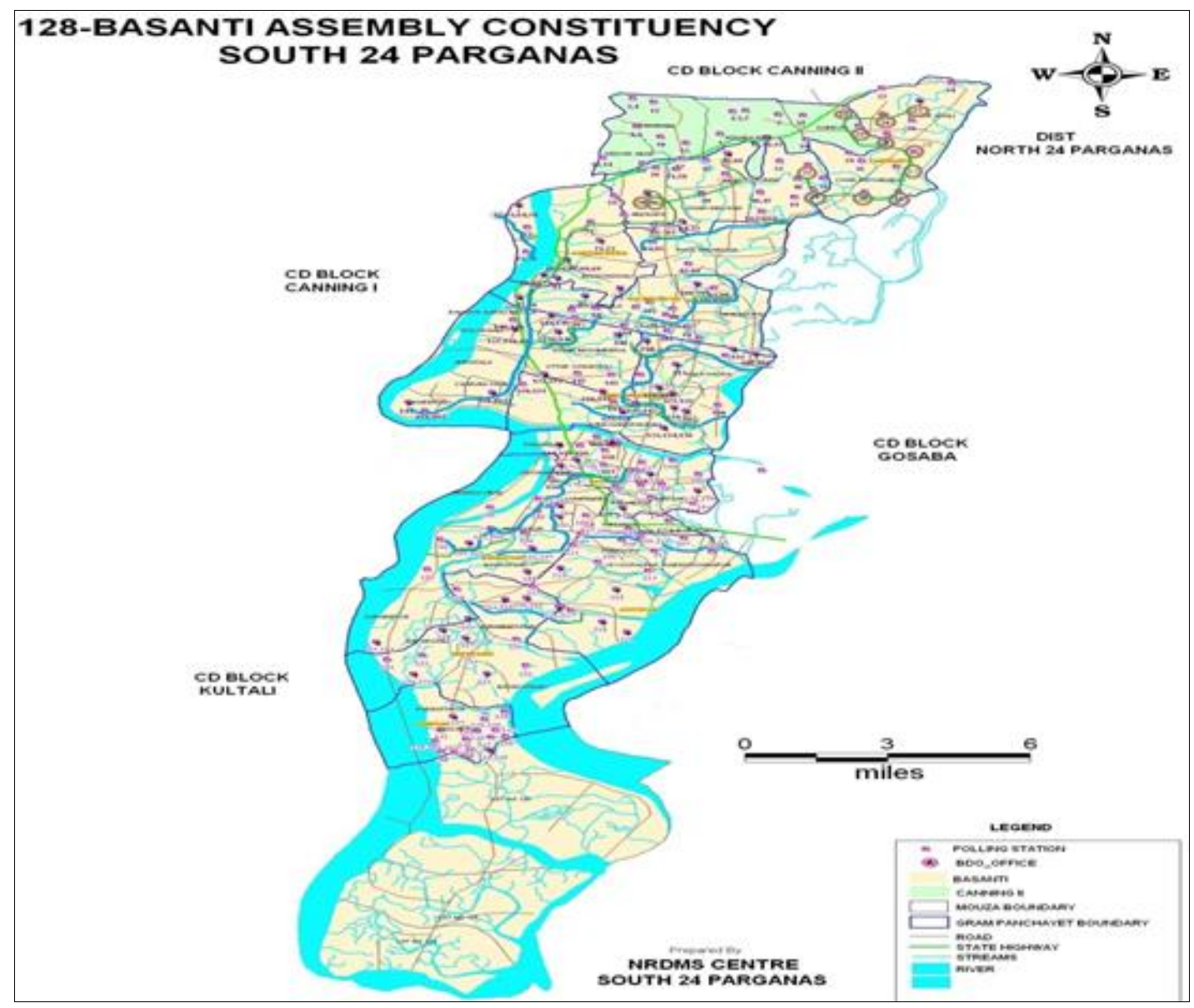

Fig 1: Map of Baria village (Source: Basanti C.D. Block office)

\section{Topography}

Baria village is comprised of the marine-riverine delta with an average elevation of 6 meters $(20 \mathrm{ft})$. This area is a sedimentary depositional plain with a unique geological structure. The soil in this region is alkaline due to the excessive presence of sodium chloride, which makes this soil more fertile and scanty. The soil is also classified as Gangetic alluvial soil and Saline soil. The texture varies from stiff clay to clay loam in varies places of the region (MSME-Development Institute Kolkata).

\section{Climatic condition}

A hot and humid climate classifies the village. It receives adequate rainfall from South-East monsoons which set in the latter half of June and withdraw by the mid of October. Pre-monsoon rains are received during March-April. The average rainfall raised to $1800 \mathrm{~mm}$. Due to high temperature as high as $40^{\circ} \mathrm{C}$, May become the hottest month and in January the temperature as low as $10^{\circ} \mathrm{C}$ (District Statistical Handbook, South 24 Parganas, 2009).

\section{Population \& Literacy rate}

The total population of Basanti CD Block is 336,717 (census: 2011). Among them, 4,881 people live in Baria village. There are about 998 houses in Baria village (2493: male, 2388: female). This village is comprised of 4881 Bhumij tribal population. Literacy rate in this village is $69.1 \%$. The female literacy rate is as low as $58.2 \%$, compared to the total number of literate population in Basanti CD Block 110,229 (56\%) males and 85,137 (44\%) females ("C.D. Block Wise Primary Census Abstract Data"). 


\section{Menstrual Hygiene Management practice scenario among tribal women}

The Government of India has implemented various scheme related to menstrual hygienic and sanitation practice in recent past years. This program mainly targeted is to improve public health from local to national level. An accessible sanitation facility is one of the essential components of women's overall health, along with her menstrual hygiene maintenance (http://www.nrhmhp.gov.in/content/menstrual-hygieneprogramme, Retrieved Date: 25.9.2019). In the ground of tribal society, women believe in certain customs related to menstrual hygiene. With the decay, these customs turned into taboos and myth (https://www.npr.org/sections/goatsandsoda/2015/08/11/431 605131/attention-trump-some-cultures-treat-menstruationwith-respect). These taboos and myths lead them towards an unhygienic menstrual life.

On the other hand, due to social segregation, many tribal groups may not able to access better menstrual products and better health facilities. Unsafe menstrual practice, along with poor personal hygiene, results in tribal women facing many gynaecological problems. Urinal tract infections due to lack of hygiene during menstruation is an underlying phenomenon which has been reported in many studies (https://mwia.net/wp-content/uploads/2012/12/Menstrual-

Hygiene.pdf). Cultural beliefs, taboos, lack of awareness, inadequate supportive infrastructure, and poor financial condition of the family are observed to be significant deterrents to improve menstrual hygiene-related issues (Ten, 2007) [9]. Among the tribes, menstruation is a topic for private discussion only. All menstrual issues and material are to be hidden from others, especially the male members of the family. If the males come to know about this, it is a cause of shame and embracement for the women. Women have to silently deal with menstruation and have to keep their menstrual material secretly and even have to dispose of these most mysteriously. All this indicates that among the selected tribal group (Bhumij) today also menstruation continues to be misty by many strict socio-cultural taboos and restrictions from the classic era. Therefore, tools and techniques of qualitative and qualitative research methodology are employed to undertake this study to understand the menstrual hygiene related issued among them. This practice prone towards unhygienic lifestyle is also a significant issue for the tribal women measured.

\section{Background Information on the considered Respondent group}

Etymologically the term 'Bhumij' denotes one who is born "out of the soil". Bhumij is the dominant Scheduled Tribe of Odisha and mainly found in the district of Mayurbhanj, but nowadays this large group of the tribe also settle down in different parts of the country mainly in West Bengal. According to their oral tradition, their original abode was in Tamulia of Bihar. They are believed to be a branch of the Munda tribe. Racially, they are of Proto-Australoid in origin. They are dolichocephalism and platyrrhine people with wavy hair and a dark complexion. Now, they have become multi-lingual and are conversant in local languages like Odia, Hindi, and Bengali also (Ota et al. ${ }^{[12]}$, Scheduled Castes and Scheduled Tribes Research and Training Institute, 2014).

\section{Methods and Methodology}

A cross-sectional study was performed in Baria village. A pre-designed and pre-tested questionnaire was made during the study after being tested on a pilot project basis on the targeted geographical area. Door to door questioner survey in the villages was done. In terms of the socio-economic parameter, the population is almost homogeneous, so representative data are selected for the analysis purpose. Seventy women were selected for the study, whose age group varies from 14-47. The field was visited in the monsoonal post-period (December-January: 2019-2020). Purposive random sampling technique was considered, and women were interviewed regarding their knowledge, and practices on menstruation-related issues. Then the data was compiled and analyzed with the help of statistical techniques.

\section{Result and Discussion}

In this study, it is observed that during menstruation time, the women uses different types of materials based on their comfort level. Women are trying to cop up with this physical situation in their ways.

Table 1: Mainly shows that mainly the youth generation preferred to use sanitation pads during menstruation.

\begin{tabular}{|c|c|c|c|c|}
\hline $\begin{array}{c}\text { Percentage of women taking part in } \\
\text { the study }\end{array}$ & Using material during menstruation & $\begin{array}{c}\text { Age } \\
\text { Group }\end{array}$ & $\begin{array}{c}\text { Education } \\
\text { Qualification }\end{array}$ & $\begin{array}{c}\text { Family } \\
\text { Income }\end{array}$ \\
\hline $63.18 \%$ & Cotton cloths & $38-47$ & Up to class ix & $<5000 /$ \\
\hline $20.40 \%$ & Market available Sanitary Pads & $14-30$ & Up to class $\mathrm{x}$ & $5000-8000 /$ \\
\hline $16.42 \%$ & Both cotton cloths and sanitary pads & $14-39$ & From class viii-x & $5000-8000 /$ \\
\hline
\end{tabular}

Table 1 mainly shows that mainly the youth generation preferred to use sanitation pads during menstruation. The demand for sanitation pads is high among the school going girls because they are linkage free. As mention above, $63.18 \%$ of women used traditional methods during menstruation, but among them, $48.95 \%$ of women preferred to use cloths. They are satisfied and comfortable whatever they are using. However, $14.23 \%$ of them are not comfortable with cloths because of their soggy feelings. They sometimes faced itchiness, awful smell and linkage problem with cloths, whenever they are going outside or doing heavy work. However, for buying a sanitary pad is a luxury because the average income of the family lies below rs.5000/ per month. Women and school going girls mainly get information related to sanitary pads from peer groups and advertisements. Those who are using sanitary pads, they curtail their daily expenditure and invent the money for buying it. School going girls are sometimes collect sanitary pads from the school with the minimum price rs.3rs.3.50/per pad, whereas the market price of a single sanitary pad varies from rs. 8 to rs.10 depending on the brand. Still, girls are not satisfied with these sanitary pads which are given from the school. The size does not fulfil the requirement as well as the blood holding capacity lasting only up to 1 to $2 \mathrm{hrs}$. As mentioned above, $16.42 \%$ of women used both sanitary pads and cloths. Mainly in the 
monsoon season because of the problem of drying the clothes, they prefer to use sanitary pads, but throughout the year they cannot effort sanitary pads due to its high price. According to the study, $66.7 \%$ of women use only water to clean their vagina because they believed that using soap may be created infection during this period (Fig. 2).

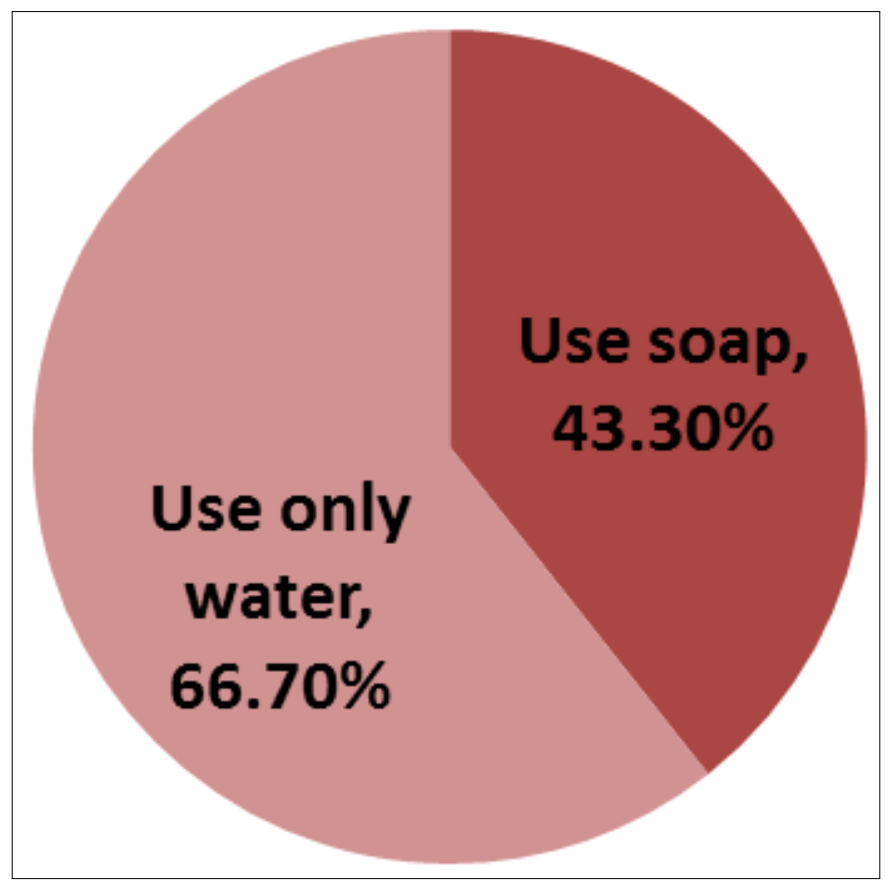

Fig 2: According to the study, $66.7 \%$ of women use only water to clean their vagina because they believed that using soap may be created infection during this period

There is no taboo related to bathing during the menstruation period. $99.8 \%$ of the women took a bath every day during menstruation. Only a negligible percentage of women $(0.2 \%)$ bath after the bleeding had stopped. The below figure (Fig: 3) shows the drying process used by the village women after cleaning their cloths with detergent.

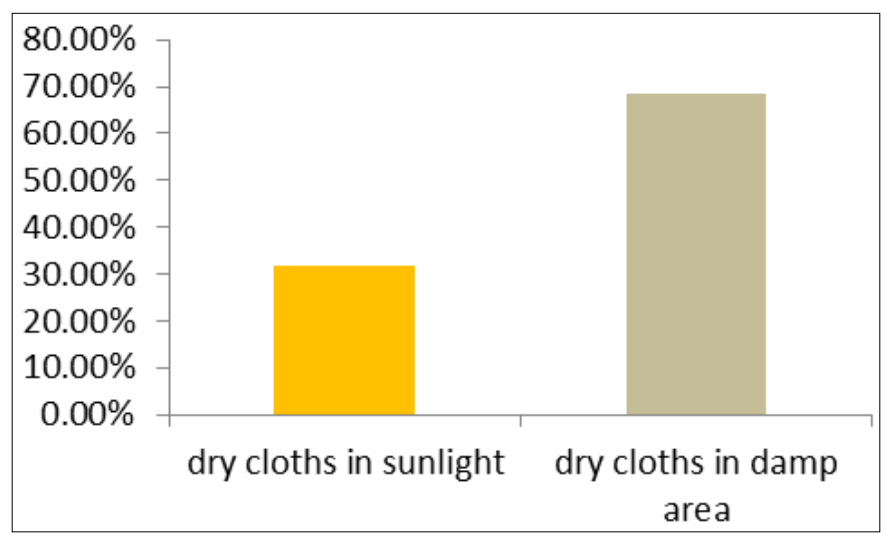

Fig 3: Shows the drying process used by the village women after cleaning their cloths with detergent

In this bar graph (Fig: 3) it is revealed that almost $68.4 \%$ of women dry their using menstrual cloths in a damp or dark area. So these clothes are not properly dry, and it is smelled awfully. Because of shame, they are refused to dry the clothes openly under sunlight. Among them, 23.5\% think that these cloths may be used for the black magic purpose also, so they do not want to dry them in the open area.
Table 2: Show that almost $71 \%$ of women use a cloth for 1 to 2 times only, whereas $7.9 \%$ of women are using cloths 5 to 6 times

\begin{tabular}{|c|c|}
\hline $\begin{array}{c}\text { Percentage of women } \\
\text { participating in the survey }\end{array}$ & $\begin{array}{c}\text { Frequency of reuse one } \\
\text { cloth }\end{array}$ \\
\hline $71.7 \%$ & $1-2$ times \\
\hline $20.4 \%$ & $3-4$ times \\
\hline $7.9 \%$ & $5-6$ times \\
\hline
\end{tabular}

The above Table: 2 show that almost $71 \%$ of women use a cloth for 1 to 2 times only, whereas $7.9 \%$ of women are using cloths 5 to 6 times. These figures indicate the fact that though cloths can be used several times without proper drying, these can create a bacterial infection in the urinal tract. On the other hand, those who used sanitary pads the changing time differ based on availability and buying capacity of the product and also depended on blood flow. The table (table: 3) shows the frequency of changing sanitary pads in a day by the women in the village.

Table 3: Shows the frequency of changing sanitary pads in a day by the women in the village

\begin{tabular}{|c|c|}
\hline $\begin{array}{c}\text { Percentage of women } \\
\text { participating in the survey }\end{array}$ & $\begin{array}{c}\text { No. of pad changing time in } \\
\text { a day. }\end{array}$ \\
\hline $41.8 \%$ & $2-3$ time/ day \\
\hline $33.5 \%$ & $3-4$ times/day \\
\hline $24.7 \%$ & 1 time/day \\
\hline
\end{tabular}

Along with the various useable products, one of the most inseparable aspects with this whole concept is the disposable method of those menstrual wastes. The materials that are used by the Bhumij women during their menstrual period, it is essential to dispose of that product properly so that the environment would not be polluted. In this research, it is seen that women who are using cloths are mostly reused them for 2 to 3 times and buried them in the mud of the pond and case of sanitary pads, women also buried them in the same way.

There is a dilemma in this discussion, which plays a very circuital role in this research. Commercial sanitary pads are composed mainly artificial fragrances to neutralizers' order, chemical soup, laced with artificial colours, polyester, adhesives, polythene (P.E.T.), polypropylene and propylene glycol (P.E.G.) (http://consumpediamed.com/wpcontent/uploads/link-impactes_EN.pdf), which are prone for hormone disruption, cancer, congenital disabilities, dryness, and infertility (https://www.heydaycare.com/blog/5-healthrisks-of-poor-menstrual-hygiene/). These pads contain mainly non-biodegradable material, so it takes almost 500800 years to compose in the soil (https://fit.thequint.com/her-health/sanitary-waste-in-india). With all the above problems associated with commercial sanitary pads, studied women mostly wanted to use sanitary pads because of its comfort and hygiene purpose. This study also found that a disparity of using sanitation pads and cloths only based on the economic level of the target family groups.

Those who used clothes mostly they are not able to dry those clothes, so bacterial growth is a ubiquitous feature on those wet cloths. In most of the cases, women are suffering from itching related problems $(89.35 \%)$, but they do not disclose their discomfort to the doctors. One reason may be that there is no female gynaecologist in the nearest health centre in the village. Accessibility and affordability are vital issues that determine the use of hygienic practice. 
Commercial pads are available in the village chemist shop. However, its disposal method is not properly guided by the health workers of the village, no proper disposal facilities are given from the governmental side, or improper instruction is written on the packet of the pads.

Significant of the study: The Government of India has launched the sanitation drive along with the menstrual hygiene to provide access to sanitation facilities to everyone to improve public health from the grass-root level. Women need to make use of those available sanitation facilities and menstrual product properly. The cultural taboos associated with menstrual cycles and their privacy during these days is not available. They use pieces of cloths to soak menstrual blood, instead of using other alternatives because of financial constraints, issues in procurement of fresh napkins, disposal of used napkins and lack of awareness of alternative materials. Each of the sanitary material requires to be used with caution and care, which requires awareness and training the tribal women for its use. Sanitary napkins are the only workable alternatives because the Government of India has launched a scheme to provide the same through ASHA workers at an affordable price. However, these are not available in every corner in the rural areas. Cultural taboos, beliefs and inhibitions require to be addressed along with sensitizing the women on alternative and affordable sanitary products to help improve menstrual hygiene and women's overall health.

\section{Conclusion}

Globalization of bio-friendly sanitary pad is the only way to overcome the disposal problems, and it will give a comfort level to the women. Commercial sanitary pads are sold mainly in the chemist's shop and in the departmental store. The urban population may have access to them from the outlets. However, in village areas, a chemist shop is not in an adjacent place, and these are not open for 24 hours. Women in the rural area feel introvert in most of the time to buy the sanitary pads openly because in the villages every person is known to another and people are considered to be relatives or neighbours. These show a sense of discomfort to buy and sell sanitary pads in rural sectors openly. If the health workers in panchayat level may supply the ecofriendly sanitary pads to the village women, it will be better to access.

The market price of each sanitary pad varies rs.6-11. If a woman can change a pad, every 3 hrs to $4 \mathrm{hrs}$, every day they need six pads and the cost per day is rs.36-66. In four days, the average cost will be rs.144 to 264 . This price for every month is a massive burden for the tribal women in this village. In the aspect of environment cloths is the better environmental choice. They are reusable, biodegradable. It requires relatively little water to clean. However, with the social restrictions and taboos, it is difficult to dry them properly. Without considering the fact, women are repeatedly using those wet unhygienic cloth regularly. In case of commercial disposable sanitary pads, they save them in tough time to protect unwanted odour. It holds a far better flow as compared to cloths or other materials. However, the sanitary pad prevents skin from breathing, so they can irritate the skin if used regularly. Sanitary pads disposal methods are accessible for women because it can be thrown away after use. With no knowledge of how to dispose of them, most women throw them in the garbage bin or a vacant place which usually gets mixed up with dry, wet and hazardous waste. The plastic layer is used to make it stainfree, and the chemicals used in producing it get further transferred between soils, water and contaminated them, so affordable bio-degradable sanitary pad is required.

\section{Acknowledgement}

Author like to acknowledge her Ph.D. supervisor Prof. L. N. Satpati for his constant guidance and support whenever required during the work.

Conflict of interest: None

Funding: No external funding received during the work.

\section{References}

1. Ota AB, et al. Bhumij, Scheduled Castes and Scheduled Tribes Research and Training Institute (SCSTRTI), C.R.P. Square, Bhubaneswar, Orissa 2014.

2. Ahuja A, Tewari S, Awareness of Pubertal Changes among Adolescent Girls. Journal of Family Welfare 1995;041(1):46-50.

3. Bhatia JC, John C. Self-reported symptoms of gynaecological morbidity and their treatment in south India. Studies in Family Planning 1995.

4. Census of India West Bengal Series-20 Part Xii-B, District Census Handbook South Twenty Four Parganas Village and Town Wise Primary Census Abstract (P.C.A.) 2011.

5. Chaudhary RH. Socio-Economic Demographic and Reproductive Health Profiles of Adolescent in SAARC Countries, Paper presented at the South Asia Conference on Adolescence, New Delhi, India 1998.

6. Census: West Bengal - District-wise CD Blocks. Registrar General and Census Commissioner, India. Access from: C.D. Block Wise Primary Census Abstract Data (P.C.A.), Retrieved 2011-2020.

7. District Industrial Profile MSME-Development Institute Kolkata (Ministry of MSME, Govt. of India 2017-18, access from: www.msmedikolkata.gov.in., Retrieved: April 2020.

8. District Statistical Handbook, South 24Parganas, Bureau of Applied Economics \& Statistics, Government of West Bengal 2009.

9. Ten VJ. Menstrual Hygiene: A Neglected Condition for the Achievement of Several Millennium Development Goals, European Commission - Europe Aid 2007.

10. Improving Menstrual Health and Hygiene in India, Usaid From The American People, Kiawah Trust, Access from: https://www.dasra.org, Retrieved 2020.

11. Amarjit K, Balwinder A, Gurmeet KS, Neki NS. Social beliefs and practices associated with menstrual hygiene among adolescent girls of Amritsar, Punjab, India. J Int. Med Sci Acad 2012;25:69-70.

12. Khanna A, et al. Menstrual Practices and Reproductive Problems: A Study of Adolescent Girls in Rajasthan. Journal of Health Management 2005;7(1):91-107.

13. Mehra S (Ed.). Adolescent Girl: An Indian Perspective. New Delhi: Mamta Health Institute for Mother and Child 1995.

14. Maji, Subarna. A Study On Menstrual Knowledge And Practices Among Rural Adolescent Girls In Burdwan District, West Bengal, International Journal of Advanced Research 2016. 
15. Paul D. A Report of an ICMR Funded Research Project: Knowledge and Practices of Adolescent Girls Regarding Reproductive Health with Special Emphasis on Hygiene during Menstruation. New Delhi: National Institute of Public Cooperation and Child Development (NIPCCD) 2007.

16. Singh AJ. Place of Menstruation in the Reproductive lives of women of Rural North India. Indian Journal of Community Medicine 2006;31(1):10-14.

17. National Health Mission, Department of Health And Family Welfare, Government of Himachal Pradesh, Access from: http://www.nrhmhp.gov.in/content/menstrual-hygieneprogramme,Retrieved Date: May, 2020.

18. Menstrual Hygiene a Neglected Condition for the Achievement of Several Millennium Development Goals, Access from: https://mwia.net/wpcontent/uploads/2012/12/Menstrual-Hygiene.pdf,

Retrieve Date 2020.

19. Brink S. Some Cultures Treat Menstruation with Respect, access from: https://www.npr.org/sections/goatsandsoda/2015/08/11/ 431605131/attention-trump-some-cultures-treatmenstruation-with-respect, Retrieve: May 2020.

20. Raw Materials of the Components of Hygiene Products, Access from:http://consumpediamed.com/wpcontent/uploads/link-impactes_EN.pdf, Retrieved date 2020.

21. Sarma B. 5 Health Risks of Poor Menstrual Hygiene, Access from: https://www.heydaycare.com/blog/5health-risks-of-poor-menstrual-hygiene/, Retrieved date 2020.

22. Zehra R. Sanitary Pads Take 500-800 Yrs to Decompose! What's the Solution? Access from: https://fit.thequint.com/her-health/sanitary-waste-inindia, Retrieved date 2020. 